\title{
Pemberian Gonadotropin Releasing Hormone Meningkatkan Konsentrasi Hormon Testosteron pada Domba Waringin
}

\author{
(THE GONADOTROPIN RELEASING HORMONE ADMINISTRATION \\ INCREASE TESTOSTERONE LEVEL IN WARINGIN RAMS)
}

\author{
Teuku Armansyah ${ }^{1}$, Sara Febria Putri², \\ Oppi Oktaviany ${ }^{2}$, Tongku Nizwan Siregar ${ }^{3 *}$, \\ Syafruddin ${ }^{4}$, Budianto Panjaitan ${ }^{4}$, Arman Sayuti ${ }^{4}$ \\ ${ }^{1}$ Laboratorium Farmakologi, \\ ${ }^{2}$ Program Studi Pendidikan Dokter Hewan, \\ ${ }^{3}$ Laboratorium Reproduksi, ${ }^{4}$ Laboratorium Klinik, \\ Fakultas Kedoktean Hewan Universitas Syiah Kuala, \\ Jl. Teungku Hasan Krueng Kalee, No. 4, \\ Kopelma Darussalam, Banda Aceh, Aceh, Indonesia, 23111 \\ Telpon: (0651)7551536, *Email: siregar@unsyiah.ac.id
}

\begin{abstract}
ABSTRAK
Salah satu upaya untuk meningkatkan konsentrasi testosteron adalah dengan pemberian gonadotropin releasing hormone $(\mathrm{GnRH})$. Peningkatan testosteron menyebabkan peningkatan kualitas spermatozoa. Penelitian ini bertujuan mengetahui pengaruh pemberian gonadotropin releasing hormone $(\mathrm{GnRH})$ terhadap peningkatan kualitas semen dan level testosteron domba waringin. Dalam penelitian ini digunakan tiga ekor domba waringin dengan rancangan pola bujur sangkar latin 3 × 3 sehingga hewan percobaan menerima suntikan $\mathrm{NaCl}$ fisiologis sebagai kontrol (K0), 50 ìg GnRH (K1), dan 100 ìg GnRH (K2). Penampungan semen dilakukan satu kali ejakulasi/minggu, selama tiga minggu. Sampel semen dikoleksi menggunakan elektroejakulator 24 jam setelah perlakuan dan diamati warna, konsistensi, volume, motilitas, konsentrasi, viabilitas, dan abnormalitas spermatozoa. Koleksi darah untuk pemeriksaan konsentrasi hormon testosteron dilakukan 60 menit setelah penyuntikan GnRH. Analisis konsentrasi testosteron dilakukan menggunakan metode enzyme linked immunosorbent assay (ELISA). Data mengenai warna dan konsistensi semen dilaporkan secara deskriptif, sedangkan level testosteron, volume semen, motilitas, konsentrasi, viabilitas dan abnormalitas spermatozoa dianalisis dengan analisis varian. Hasil pengamatan menunjukkan bahwa warna dan konsistensi semen yang dikoleksi pada semua kelompok perlakuan adalah krem dengan konsistensi kental. Hasil analisis statistika menunjukkan bahwa volume semen, konsentrasi spermatozoa, motilitas spermatozoa, viabilitas spermatozoa dan abnormalitas spermatozoa setelah pemberian $\mathrm{GnRH}$ menunjukkan perbedaan yang tidak signifikan $(\mathrm{P}>0,05)$. Rata-rata $( \pm \mathrm{SD})$ konsentrasi testosteron pada kelompok K0, K1, dan K2 masing-masing adalah $1,82 \pm 1,08 ; 8,05 \pm 2,24 ;$ dan 8,81 $\pm 1,09 \mathrm{ng} / \mathrm{mL}(\mathrm{P}<0,05)$. Disimpulkan bahwa pemberian $\mathrm{GnRH}$ tidak memengaruhi kualitas semen namun dapat meningkatkan konsentrasi hormon testosteron pada domba waringin.
\end{abstract}

Kata-kata kunci: domba waringin; GnRH; semen; testosteron

\section{ABSTRACT}

One effort to increase testosterone concentration is by releasing gonadotropin-releasing hormone $(\mathrm{GnRH})$. Increased testosterone will cause an increase in the quality of spermatozoa. This study was aimed to determine the effect of $\mathrm{GnRH}$ on increasing semen quality and testosterone level of Waringin rams. Three Waringin rams were used in this study with 3 x 3 Latin square design. The experimental animals received physiological $\mathrm{NaCl}$ injections as control (K0), 50 ìg $\mathrm{GnRH}(\mathrm{K} 1)$, and 100 ìg $\mathrm{GnRH}(\mathrm{K} 2)$. Ejaculates were collected weekly for three weeks. Semen samples were collected using electroejaculator twenty-four hours after treatment and the color, consistency, volume, motility, concentration, viability, 
and abnormalities of spermatozoa were observed. Blood was collected to examination testosterone concentration 60 minutes after injection with $\mathrm{GnRH}$. Testosteron concentration was analyzed using the enzyme linked immunosorbent assay (ELISA) method. The data of semen quality (color and consistency) were reported descriptively, whereas level tesosterone, semen volume, motility, concentration, viability, and abnormality of spermatozoa were analyzed using analysis of variance. Statistical analysis revealed that semen volume, concentration, motility, viability, and abnormality of spermatozoa did not differ significantly $(\mathrm{P}>0.05)$ after $\mathrm{GnRH}$ administration. The results showed that the average $( \pm \mathrm{SD})$ testosterone concentration in treatments $\mathrm{K} 0, \mathrm{~K} 1$, and $\mathrm{K} 2$ were $1.82 \pm 1.08 \mathrm{ng} / \mathrm{mL} ; 8.05 \pm 2.24$ and $8.81 \pm 1.09 \mathrm{ng} / \mathrm{mL}$, respectively $(\mathrm{P}<0.05)$. It can be concluded that the administration of GnRH did not affect the semen quality but increasing the testosterone concentration in Waringin rams.

Key words: Waringin rams; GnRH; semen; testosterone

\section{PENDAHULUAN}

Domba waringin adalah domba yang berasal dari Desa Stabat, Langkat, Sumatera Utara, memiliki potensi besar untuk dikembangkan karena keunggulannya sebagai penghasil daging melebihi domba lain yang ada di Indonesia. Domba waringin berasal dari persilangan domba lokal dengan domba introduksi yang mempunyai garis keturunan domba barbados blackbelly (asal Karabia), domba saint croix (asal Kepulauan Virgin, Amerika Serikat) dan domba suffolk (asal Inggris) (Alam, 2018). Domba waringin jantan dewasa memiliki ciri khas berambut gimbal di bagian punggung dan berambut pendek di bagian perut. Persentase karkas domba waringin sekitar 55\%, yang bermakna peternak dapat memperoleh 55,0-82,5 kg daging dari bobot hewan 123-150 kg dengan catatan pemeliharaan dilakukan intensif. Bandingkan dengan persentase karkas domba lokal asal Ciawi sekitar 48,18\%. Kelebihan lain domba waringin adalah kandungan lemak yang rendah 2-3\% dan serat daging lebih halus (Rochim et al., 2014). Kandungan lemak domba berkisar antara 5-46\% tergantung tingkat kegemukan ternak (Parakkasi,1981).

Salah satu keunggulan ternak domba adalah memiliki produktivitas cepat sehingga sangat berpotensi untuk dikembangkan. Potensi pengembangan domba dapat dilakukan melalui upaya meningkatkan produktivitasnya. Peningkatan produktivitas dapat dilakukan melalui program pemuliaan dan perbaikan efisiensi reproduksi. Kinerja reproduksi berkaitan dengan peningkatan kebuntingan dan kelahiran yang sebagian ditentukan oleh faktor pejantan, dalam hal ini berkaitan dengan perkembangan saluran reproduksi untuk menghasilkan spermatozoa dalam membuahi sel telur (Hasbi dan Gustina, 2018).

Kapasitas reproduksi hewan jantan ditentukan oleh fungsi poros hipotalamus- hipofisis-testis. Gonadotropin releasing hormone $(\mathrm{GnRH})$ merupakan hormon kunci, disebabkan peranannya dalam mengontrol produksi luteinizing hormone $(\mathrm{LH})$ dan follicle stimulating hormone (FSH) dari hipofisis anterior (Azawi et al., 2012). Hormon FSH diketahui berperan dalam mengontrol proliferasi sel Sertoli yang mengakibatkan terjadinya peningkatan volume testis (Kuiri-Hanninen et al., 2011). Hormon LH tidak bekerja langsung pada proses spermatogenesis, namun merangsang sintesis dan pelepasan hormon testosteron dari sel Leydig. Testosteron berperan dalam memacu pertumbuhan dan menjaga kelangsungan fungsi kelenjar-kelenjar kelamin pelengkap untuk menghasilkan plasma semen pada saat ejakulasi, meningkatkan libido dan berperan dalam proses spermatogenesis di dalam tubulus seminiferus (Hamdan, 1999). Penurunan kadar LH, FSH dan testosteron akan mengganggu proses spermatogenesis dan memengaruhi kualitas spermatozoa (Selvage dan Rivier, 2003). Hormon GnRH telah digunakan untuk meningkatkan kapasitas reproduksi hewan jantan pada kerbau (Sajjad et al., 2007), kambing peranakan ettawa (Hamdan, 1999), dan domba awassi (Azawi et al., 2012). Glover et al. (1990) menyatakan bahwa aktivitas reproduksi pada domba juga dipengaruhi breed dan daerah asal domba tersebut. Penelitian ini bertujuan meningkatkan kualitas spermatozooa dan hormon testosteron melalui pemberian $\mathrm{GnRH}$ pada domba waringin.

\section{METODE PENELITIAN}

Penelitian ini dilaksanakan di UPT. Hewan Coba, Laboratorium Reproduksi dan Laboratorium Riset, Fakultas Kedokteran Hewan, Universitas Syiah Kuala yang dilakukan pada bulan Desember 2018 sampai dengan Januari 2019. Dalam penelitian ini 
digunakan tiga ekor domba waringin jantan berumur $\pm 2-3$ tahun.

Penelitian ini merupakan penelitian eksperimen dengan menggunakan rancangan pola bujur sangkar latin (latin square) $3 \times 3$ sehingga hewan percobaan menerima suntikan $\mathrm{NaCl}$ fisiologis sebagai kontrol (K0), 50 ìg $\mathrm{GnRH}$ (Fertagy ${ }^{\circledR}$, BV Boxmeer, Noord-Brabant, Netherlands), sebagai K1, dan 100 ìg GnRH (Fertagyl ${ }^{\circledR}$, BV Boxmeer, Noord-Brabant, Netherlands) sebagai K2. Setelah melalui masa adaptasi selama 15 hari, selanjutnya hewan percobaan diberi perlakuan dengan penyuntikan $\mathrm{GnRH}$. Setiap perlakuan dilakukan sebanyak tiga kali dan tiap perlakuan dilakukan bergantian setiap minggunya (Hamdan, 1999). Secara skematis perlakuan yang diberikan pada masing-masing hewan percobaan disajikan pada Tabel 1.

\section{Penampungan Semen}

Semen dikoleksi menggunakan elektroejakulator. Metode ini dipilih karena domba pejantan tidak mau menunggangi domba betina penggoda, sehingga metode penampungan menggunakan vagina buatan tidak dapat dilaksanakan. Sebelum probe dimasukkan ke dalam rektum, preputium dan daerah sekitarnya dibersihkan dengan $\mathrm{NaCl}$ fisiologis, dan dikeringkan dengan kertas tisu. Rambut di sekitar preputium dicukur. Penampungan semen dilakukan satu kali ejakulasi/minggu, selama tiga minggu. Interval waktu perlakuan sampai koleksi dilakukan 24 jam sesuai petunjuk Azawi et al. (2012).

\section{Pemeriksaan Makroskopis Semen}

Segera setelah ditampung, semen dievaluasi secara makroskopis berupa volume, warna, dan konsistensi sesuai petunjuk Herdis (2017).

Volume. Pemeriksaan volume dilakukan dengan menggunakan tabung penampung

Tabel 1. Pola perlakuan terhadap hewan percobaan

\begin{tabular}{llll}
\hline \multirow{2}{*}{ Subjek } & \multicolumn{3}{c}{ Periode } \\
\cline { 2 - 4 } & I & II & III \\
\hline 1 & C & A & B \\
2 & B & C & A \\
3 & A & B & C \\
\hline
\end{tabular}

Keterangan: $\mathrm{K} 0=\mathrm{NaCl}$ fisiologis; $\mathrm{K} 1=50 \mathrm{ig} \mathrm{GnRH}$; $\mathrm{K} 2=100$ ig $\mathrm{GnRH}$ semen yang mempunyai ukuran volume semen dalam $\mathrm{mL}$. Volume semen yang sudah ditampung diukur dengan melihat langsung pada tabung berskala.

Warna. Pemeriksaan warna diamati secara visual setelah penampungan semen dengan melihat langsung pada tabung penampung. Semen domba normal berwarna putih susu atau krem.

Konsistensi. Penilaian konsistensi semen dilakukan dengan memiringkan tabung penampung kemudian dikembalikan pada posisi semula. Konsistensi dapat dinilai berdasarkan kecepatan semen kembali ke dasar tabung penampung, jika semen turunnya lambat berarti konsistensinya tinggi dan jika turunnya cepat berarti konsistensinya rendah. Konsistensi semen dikatagorikan menjadi tiga yaitu konsistensi kental, sedang dan encer.

\section{Pemeriksaan Mikroskopis Semen}

Setelah ditampung, semen segera dievaluasi secara mikroskopis berupa konsentrasi spermatozoa, motilitas spermatozoa, viabilitas spermatozoa, dan abnormalitas spermatozoa.

Konsentrasi Spermatozoa. Konsentrasi spermatozoa dihitung menggunakan pipet haemocytometer dan kamar hitung Neubauer. Semen dihisap sampai skala 0,5 kemudian ditambahkan dengan larutan $\mathrm{NaCl} 3 \%$ dan diisap sampai mencapai angka 101. Larutan tersebut dihomogenkan dengan gerakan membentuk angka delapan selama 2-3 menit, kemudian dibuang beberapa tetes. Sampel diisikan ke dalam kamar hitung Neubauer (Qiujing, China) yang telah ditutup menggunakan gelas penutup. Kemudian diamati di bawah mikroskop (Olympus CX43) dengan pembesaran $40 \times 10$. Penghitungan spermatozoa dilakukan pada lima kotak besar. Konsentrasi spermatozoa yang didapatkan adalah Y x 5 x 10v (Y= jumlah spermatozoa pada lima kotak) (Mughniati et al., 2018).

Motilitas Spermatozoa. Motilitas spermatozoa dapat diamati dengan cara meneteskan spermatozoa di atas gelas objek dan ditambahkan dengan satu tetes $\mathrm{NaCl}$ fisiologis kemudian diamati di bawah mikroskop dengan pembesaran $40 \times 10$. Jumlah spermatozoa motil dihitung berdasarkan pergerakan spermatozoa yaitu jumlah progresif cepat (A), jumlah progresif lambat (B), jumlah sirkuler (C), dan jumlah fibrasi (D). Spermatozoa yang diamati maksimal sebanyak 200 sel dalam lima lapangan pandang (Herdis, 2017) Penentuan 
persentasi motilitas spermatozoa yakni: \% motilitas $=\left[\mathrm{A} \times(\mathrm{A}+\mathrm{B}+\mathrm{C}+\mathrm{D})^{-1}\right] \times 100 \%$

Viabilitas Spermatozoa. Pemeriksaan terhadap viabilitas spermatozoa dilakukan dengan cara meneteskan satu tetes semen di gelas objek dan tambahkan dengan satu tetes pewarnaan eosin $2 \%$. Preparat apus dibuat dan difiksasi di atas api Bunsen, setelah itu dilakukan pemeriksaan menggunakan mikroskop dengan pembesaran 40 x 10 . Spermatozoa yang hidup tidak berwarna sedangkan spermatozoa yang mati terwarnai dengan pewarnaan eosin. Penentuan persentasi spermatozoa yang hidup digunakan rumus yang diterapkan oleh WHO (1999), yakni: \% hidup = [(jumlah spermatozoa hidup) x (jumlah spermatozoa hidup dan mati) $\left.{ }^{-1}\right]$ x $100 \%$

Abnormalitas Spermatozoa. Analisis morfologi dapat diamati pada sediaan apusan yang menggunakan pewarnaan eosin $2 \%$. Dengan meneteskan satu tetes semen pada gelas objek lalu diteteskan eosin kemudian difiksasi di atas api Bunsen, dan diamati dengan menggunakan mikroskop cahaya pembesaran 40 $\mathrm{x}$ 10. Pemeriksaan morfologi dilihat dari kelainan bentuk atau abnormalitas spermatozoa yang meliputi: abnormalitas primer (ukuran kepala kecil/besar, kepala ganda atau ekor ganda, dan bentuk kepala tidak normal) dan abnormalitas sekunder (kepala pecah, ekor putus pada bagian leher atau tengah-tengah, dan ekor melipat). (Soehadi dan Arsyad, 1983). Spermatozoa yang diamati maksimal sebanyak 200 sel dalam lima lapangan pandang dan penghitungan dilakukan dengan rumus: \% abnormalitas $=[$ (jumlah spermatozoa abnormal $)$ $\mathrm{x}$ (jumlah spermatozoa abnormal dan normal) $\left.{ }^{-1}\right]$ $\mathrm{x} 100 \%$

\section{Pengambilan Sampel Darah}

Sampel darah dikoleksi 60 menit setelah penyuntikan GnRH (Hamdan, 1999). Darah dikoleksi tanpa diberi antikoagulan sebanyak 3 $\mathrm{mL}$ melalui vena jugularis menggunakan spuit $3 \mathrm{~mL}$. Darah yang telah dikoleksi, kemudian dimasukkan ke dalam tabung sentrifus dan didiamkan selama 60 menit sampai membeku dan terpisah antara serum darah dengan bendabenda darah (clot). Setelah serum dan benda darah terpisah, kemudian disentrifugasi dengan kecepatan $1200 \mathrm{rpm}$ selama 10 menit, serum diambil dan dimasukkan ke dalam microtube dan disimpan di dalam freezer dengan suhu $20^{\circ} \mathrm{C}$ (Gholib et al., 2016).

\section{Analisis Hormon Testosteron}

Analisis hormon dilakukan mengikuti prosedur dari katalog testosteron. Larutan standar 0,2 $\mathrm{ng} / \mathrm{mL}$ sampai $16 \mathrm{ng} / \mathrm{mL}$ disiapkan. Sampel dan larutan standar yang telah disiapkan dimasukkan masing-masing $25 \mu \mathrm{L}$ ke dalam sumur microplate. Setelah itu, $200 \mu \mathrm{L}$ enzim konjugasi ditambahkan ke masingmasing sumur dan campuran tersebut diinkubasi selama 60 menit pada suhu kamar. Setelah inkubasi, microplate dicuci tiga kali menggunakan washing solution pada masingmasing sumur sebanyak $300 \mu \mathrm{L}$. Setelah itu, larutan substrat $200 \mu \mathrm{L}$ ditambah ke masingmasing sumur. Plate diinkubasi selama 15-20 menit pada suhu kamar. Reaksi enzim dihentikan dengan menggunakan stop solution sebanyal $100 \mu \mathrm{L} \mathrm{0,5} \mathrm{M} \mathrm{H}_{2} \mathrm{SO}_{4}$ ke masing-masing sumur dan dilakukan pembacaan absorban dengan menggunakan ELISA reader (Pratomo dan Yudi, 2016).

\section{Analisis Data}

Data mengenai warna dan konsistensi semen dilaporkan secara deskriptif, sedangkan level testosteron, volume semen, motilitas, konsentrasi, viabilitas, dan abnormalitas spermatozoa dianalisis menggunakan uji sidik ragam pola bujur sangkar latin.

\section{HASIL DAN PEMBAHASAN}

Warna dan konsistensi semen yang dikoleksi dari domba waringin pada semua perlakuan memperlihatkan warna krem dan konsistensi kental. Kondisi tersebut sesuai dengan pendapat Toelihere (1993) yang menyatakan bahwa warna dan konsistensi semen domba yang normal yaitu seperti susu atau krem keputih-putihan dan keruh dengan konsistensi semen adalah encer hingga kental. Hasil pemeriksaan volume, konsentrasi, motilitas, viabilitas, dan abnormalitas spermatozoa domba waringin pada ketiga kelompok perlakuan yaitu kelompok $\mathrm{NaCl}$ fisiologis (K0), 50 ìg GnRH (K1), dan 100 ìg GnRH (K2) disajikan pada Tabel 2.

Rata-rata volume semen domba waringin berkisar antara 0,97-1,13 mL seperti yang disajikan pada Tabel 2. Hasil penelitian ini sesuai dengan pendapat Garner dan Hafez (2000) bahwa volume semen domba rata-rata berkisar antara 0,8-1,2 $\mathrm{mL}$ per ejakulat. Hasil analisis statistika menunjukkan bahwa pemberian 
Tabel 2. Rataan level testosteron, volume, konsentrasi, motilitas, viabilitas, dan abnormalitas spermatozoa domba waringin dengan perlakuan gonadotropin releasing hormone/GnRH

\begin{tabular}{lccr}
\hline \multirow{2}{*}{ Peubah } & \multicolumn{3}{c}{ Kelompok perlakuan } \\
\cline { 2 - 4 } & Kontrol & 50 ìg GnRH & 100 ìg GnRH \\
\hline Volume $(\mathrm{mL})$ & $1,07 \pm 0,25^{\mathrm{a}}$ & $1,13 \pm 0,15^{\mathrm{a}}$ & $0,97 \pm 0,21^{\mathrm{a}}$ \\
Konsentrasi $\left(10^{6} / \mathrm{mL}\right)$ & $1.076,67 \pm 902,89^{\mathrm{a}}$ & $718,33 \pm 67,52^{\mathrm{a}}$ & $953,33 \pm 513,77^{\mathrm{a}}$ \\
Motilitas $(\%)$ & $41,00 \pm 27,51^{\mathrm{a}}$ & $52,00 \pm 17,52^{\mathrm{a}}$ & $57,67 \pm 46,80^{\mathrm{a}}$ \\
Viabilitas $(\%)$ & $70,00 \pm 8,72^{\mathrm{a}}$ & $77,00 \pm 10,15^{\mathrm{a}}$ & $70,00 \pm 7,55^{\mathrm{a}}$ \\
Abnormalitas $(\%)$ & $30,00 \pm 24,56^{\mathrm{a}}$ & $16,33 \pm 6,43^{\mathrm{a}}$ & $20,00 \pm 13,23^{\mathrm{a}}$ \\
Testosteron $(\mathrm{ng} / \mathrm{mL})$ & $1,82 \pm 1,08^{\mathrm{a}}$ & $8,05 \pm 2,24^{\mathrm{b}}$ & $8,81 \pm 1,09^{\mathrm{b}}$ \\
\hline
\end{tabular}

Keterangan: ${ }^{a, b}$ Superskrip huruf yang berbeda pada baris yang sama menunjukkan perbedaan yang nyata $(\mathrm{P}<0,05)$

GnRH tidak berpengaruh $(\mathrm{P}>0,05)$ terhadap peningkatan volume semen. Hasil yang sama dilaporkan oleh Sajjad et al. (2007), terdapat efek yang tidak signifikan setelah pemberian GnRH terhadap volume semen kerbau. Rata-rata volume semen kerbau pada kelompok kontrol yaitu $4,4 \mathrm{~mL}$ dan pada kelompok yang mendapatkan $200 \mu \mathrm{g}$ GnRH yaitu 6,22 mL. Namun, Azawi et al. (2012) melaporkan hal yang sebaliknya. Pemberian GnRH berpengaruh terhadap peningkatan volume semen domba awassi. Rata-rata volume semen domba awassi pada kelompok perlakuan $50 \mu \mathrm{g}$ GnRH yaitu 1,52 $\mathrm{mL}$ (breeding season) dan 1,2 $\mathrm{mL}$ (non breeding season) mengalami peningkatan dibandingkan dengan kelompok kontrol yaitu 1,1 mL (breeding season) dan 0,96 $\mathrm{mL}$ (non breeding season). Perbedaan efek tersebut kemungkinan disebabkan oleh perbedaan respons hewan dan waktu koleksi semen setelah penyuntikan. Waktu koleksi semen pada penelitian Sajjad et al. (2007) dilakukan 12 jam setelah penyuntikan, sedangkan Azawi et al. (2012) semen dikoleksi 24 jam setelah penyuntikan GnRH.

Perbedaan volume semen pada saat penampungan dipengaruhi oleh perbedaan individu ternak, bangsa ternak, umur, nutrisi, frekuensi ejakulasi, interval koleksi semen dan cara koleksi semen (Tambing et al., 2003). Perbedaan volume semen antara domba waringin pada penelitian ini dengan domba awassi (Azawi et al., 2012) setelah perlakuan dengan GnRH kemungkinan dapat terjadi akibat perbedaan bangsa ternak. Perbedaan bangsa ternak memengaruhi libido. Pejantan dengan libido yang tinggi, menghasilkan spermatozoa yang banyak (Ahmad et al., 2005). Perbedaan bangsa domba juga dapat menunjukkan perbedaan kemampuan adaptasi dengan lingkungan. Perbedaan nutrisi selama penelitian kemungkinan dapat memengaruhi volume semen. Domba awwasi (Azawi et al., 2012) dikondisikan dalam kandang yang sesuai dan diberi pakan konvensional dengan nutrisi yang tepat sedangkan domba waringin yang digunakan hanya diberikan pakan hijauan segar. Produktivitas ternak domba sangat dipengaruhi oleh kualitas pakan yang diberikan (Dewi dan Hidayat, 2018). Selanjutnya perbedaan teknik koleksi semen kemungkinan juga memengaruhi volume semen. Cara koleksi semen pada domba waringin menggunakan elektroejakulator sedangkan pada domba awwasi (Azawi et al., 2012) menggunakan vagina buatan. Toelihere (1993) menyatakan penggunaan vagina buatan merupakan teknik yang sesuai untuk mendapatkan semen yang bersih, maksimal, dan spontan keluar.

Warna, konsistensi, dan konsentrasi saling berhubungan erat satu sama lain. Semakin kental semen yang dihasilkan oleh ternak, maka konsentrasi semakin tinggi dan warna semakin pekat (Sujoko et al., 2009). Pada penelitian ini pemberian $\mathrm{GnRH}$ tidak memengaruhi $(\mathrm{P}>0,05)$ konsentrasi spermatozoa domba waringin. Hal ini kemungkinan disebabkan rendahnya respons domba waringin terhadap GnRH. Respons terhadap GnRH kemungkinan dipengaruhi breed dan spesies. Azawi et al. (2012) melaporkan pengaruh GnRH terhadap peningkatan konsentrasi spermatozoa domba awwasi. Hamdan (1999) juga melaporkan adanya pengaruh GnRH terhadap peningkatan konsentrasi spermatozoa pada kambing peranakan ettawah yaitu berkisar antara 3.833,3-5.616,7(106/mL). Monaco et al. (2015), 
melaporkan bahwa pemberian GnRH berpengaruh terhadap peningkatan konsentrasi spermatozoa pada unta yaitu berkisar antara 491,2-1.085,1(10\%/mL). Namun, Sajjad et al. (2007) melaporkan hal yang sebaliknya, pemberian GnRH tidak berpengaruh terhadap konsentrasi spermatozoa kerbau yaitu berkisar antara 0,75-0,92(106/mL).

Pemberian GnRH tidak memengaruhi $(\mathrm{P}>0,05)$ motilitas spermatozoa. Dalam penelitian ini, rata-rata persentase motilitas spermatozoa domba waringin berkisar antara 41,00-57,67\% (Tabel 2). Hal tersebut sesuai dengan laporan Azawi et al. (2012), bahwa pemberian $\mathrm{GnRH}$ tidak berpengaruh terhadap motilitas spermatozoa domba awwasi. Namun, rata-rata motilitas spermatozoa domba waringin pada penelitian ini lebih rendah dibandingkan dengan domba awwasi yang dilaporkan oleh Azawi et al. (2012) yaitu motilitas spermatozoa domba awwasi berkisar antara 92,0-94,2\% (breeding season) dan 82,3-90,6\% (nonbreeding season). Meskipun secara statistika tidak berpengaruh, namun nilai rata-rata persentase motilitas spermatozoa cenderung mengalami peningkatan pada domba yang mendapat perlakuan dengan 50 dan 100 ìg GnRH dibandingkan kontrol. Faktor-faktor yang dapat memengaruhi motilitas spermatozoa yaitu bangsa, individu, umur ternak, jumlah ejakulat dan perubahan suhu (Johnson et al., 2000; Tamoes et al., 2014). Perbedaan persentase motilitas pada penelitian ini kemungkinan disebabkan oleh perbedaan bangsa ternak dan perubahan temperatur. Perbedaan bangsa akan mengakibatkan perbedaan adaptasi terhadap lingkungannya. Salah satu faktor lingkungan yaitu suhu. Suhu berpengaruh terhadap produksi ternak jantan. Suhu yang terlalu tinggi atau rendah dapat mengganggu termoregulasi pada scrotum sehingga fungsi scrotum terganggu dan mengakibatkan terganggunya proses spermatogenesis (Ismaya, 2014).

Rata-rata viabilitas spermatozoa (Tabel 2) berkisar antara 70-77\%. Hasil analisis statistika menunjukkan bahwa pemberian $\mathrm{GnRH}$ tidak memengaruhi $(\mathrm{P}>0,05)$ viabilitas spermatozoa domba waringin. Penyebab tidak berpengaruhnya perlakuan pemberian GnRH kemungkinan berkaitan dengan breed atau spesies. Azawi et al. (2012) melaporkan bahwa GnRH tidak berpengaruh terhadap viabilitas spermatozoa, namun nilai rata-rata viabilitas spermatozoa domba awwasi cenderung lebih tinggi yaitu berkisar antara 85,83-89,5\% (breeding season) dan 81,66-87,18\% (nonbreeding season). Sebaliknya, nilai rata-rata viabilitas spermatozoa unta yang dilaporkan Monaco et al. (2015) cenderung lebih rendah yaitu berkisar antara 54,1-66,3\%. Perbedaan tersebut kemungkinan disebabkan perbedaan bangsa ternak. Viabilitas merupakan daya hidup spermatozoa yang digunakan sebagai salah satu indikator kualitas spermatozoa. Daya hidup spermatozoa di luar tubuh sangat rendah dan mudah sekali mengalami kematian (Sandra et al., 2016). Persentase hidup spermatozoa tergantung pada keutuhan membran plasma. Membran plasma yang rusak dapat memengaruhi fungsi fisiologis dan metabolisme spermatozoa sehingga menyebabkan spermatozoa mati.

Rata-rata persentase abnormalitas spermatozoa cenderung lebih rendah pada domba yang mendapatkan perlakuan $\mathrm{GnRH}$ dibandingkan dengan kontrol seperti yang disajikan pada Tabel 2. Hasil analisis statistika menunjukkan bahwa pengaruh antar perlakuan terhadap abnormalitas spermatozoa domba waringin tidak berbeda nyata $(\mathrm{P}>0,05)$. Hasil abnormalitas spermatozoa domba waringin sesuai dengan pendapat Garner dan Hafez (2000) yang menyatakan bahwa abnormalitas spermatozoa domba berkisar antara 5-20\%. Persentase abnormalitas spermatozoa domba yang mendapat perlakuan 50 dan 100 ìg GnRH yaitu sebesar 16,33\% dan 20\% cenderung lebih rendah dibandingkan kontrol yaitu 30\%. Hal yang sama juga dilaporkan oleh Sajjad et al. (2007) bahwa pemberian GnRH dapat menurunkan abnormalitas spermatozoa pada kerbau.

Abnormalitas spermatozoa terdiri dari abnormalitas primer dan sekunder. Abnormalitas spermatozoa primer terjadi akibat kegagalan dalam proses spermatogenesis di tubuli seminiferus. Abnormalitas spermatozoa primer dapat dipengaruhi oleh faktor keturunan dan faktor lingkungan yang buruk. Abnormalitas spermatozoa primer meliputi spermatozoa berkepala besar, kepala kecil, kepala pendek, lebar dan ekor ganda (Barth dan Oko, 1989). Abnormalitas spermatozoa sekunder kemungkinan besar disebabkan perlakuan pada saat pewarnaan dalam proses pembuatan preparat ulas (Garner dan Hafez, 2000). Abnormalitas spermatozoa berkaitan dengan kemampuan membuahi sel telur dan kemandulan pada berbagai spesies. Struktur sel yang abnormal dapat menyebabkan gangguan dan hambatan pada saat fertilisasi sehingga 
menyebabkan rendahnya angka implantasi maupun kebuntingan (Afiati et al., 2015). Abnormalitas morfologi spermatozoa selalu ditemukan dalam setiap ejakulasi, namun mempunyai dampak yang berbeda terhadap fertilitas. Beberapa di antaranya dapat menghambat pembuahan, sementara yang lain, seperti kelainan kepala spermatozoa pear shape dapat mengganggu perkembangan embrio (Rodriquez dan Barth, 2007). Jumlah spermatozoa abnormal dalam semen yang mencapai 20\% tidak menyebabkan penurunan angka fertilitas (Hafez dan Hafez, 2000).

Peningkatan testosteron kemungkinan terlibat secara langsung maupun tidak langsung dalam menurunkan abnormalitas spermatozoa (Herbert et al., 2004; Sajjad et al., 2007). Ratarata konsentrasi testosteron domba waringin pada kelompok K0; K1; dan K2 masing-masing adalah 1,82 $\pm 1,08 ; 8,05 \pm 2,24 ;$ dan $8,81 \pm 1,09 \mathrm{ng} /$ $\mathrm{mL}$. Berdasarkan hasil analisis statistika pengaruh perlakuan terhadap kadar testosteron serum yang dikoleksi 60 menit setelah perlakuan pada ketiga kelompok menunjukkan perbedaan yang nyata $(\mathrm{P}<0,05)$.

Hasil kadar testosteron pada penelitian ini pada kelompok kontrol relatif lebih rendah dibandingkan dengan kandungan testosteron domba garut $(3,46 \pm 3,2 \mathrm{ng} / \mathrm{mL})$, domba malin $(2,31 \pm 0,42 \mathrm{ng} / \mathrm{mL})$, dan domba canada $(3,5 \pm 1,2$ ng/mL) (Wahid dan Yunus, 1995). Perbedaan tersebut kemungkinan disebabkan oleh individu ternak yang dipengaruhi oleh faktor genetik dan faktor lingkungan (Sukaryana et al., 2011). Pakan dengan nutrisi yang rendah dapat menurunkan kadar testosteron sehingga produktivitas ternak juga ikut menurun. Testosteron merupakan hormon steroid yang memiliki efek anabolik dan androgenik. Otot termasuk salah satu target organ dari testosteron (Bain, 2010).

Konsentrasi testosteron pada penelitian ini pada dosis 50 ìg GnRH adalah 8,05 $\pm 2,24 \mathrm{ng} / \mathrm{mL}$. Hasil ini relatif serupa dengan laporan Schanbacher (1978), yakni sebesar 7,79 $\pm 0,80 \mathrm{ng} /$ $\mathrm{mL}$ setelah perlakuan dengan 50 ìg GnRH dua kali sehari selama 56 hari pada delapan ekor domba jantan. Hasil tersebut menunjukkan bahwa domba yang diberikan perlakuan GnRH dapat meningkatkan kadar testosteron serum hampir dua kali lipat dibandingkan dengan

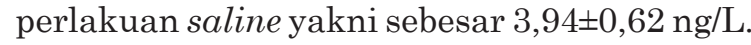
Hasil yang serupa juga dilaporkan oleh Hamdan (1999), bahwa terjadi peningkatan kadar testosteron kambing peranakan ettawa pada perlakuan 50 ìg GnRH yakni sebesar 8,28 40,99 ng/mL setelah 60 menit pemberian. Purswell dan Wilcke (1993), juga melaporkan bahwa pemberian 50 ìg GnRH, secara intramuskuler pada anjing jantan menunjukkan peningkatan yang signifikan 60 menit setelah diberikan perlakuan dan konsentrasi testosteron telah kembali ke kadar awal setelah empat jam perlakuan.

Efek GnRH pada domba waringin sangat tergantung pada dosis yang digunakan pada saat penyuntikan. Kadar testosteron pada kelompok perlakuan 50 ìg maupun 100 ìg GnRH mengalami peningkatan meskipun secara statistika menunjukkan perbedaan yang tidak nyata ( $\mathrm{P}>0,05)$. Knol et al. (1993), melaporkan bahwa perlakuan dengan dosis $0 ; 0,01 ; 1 ; 10$; dan 100 ìg GnRH pada anjing mengalami peningkatan konsentrasi testosteron setelah 60 menit perlakuan masing-masing sebesar $16 \pm 4$; $20 \pm 4 ; 22 \pm 3 ; 22 \pm 4 ; 24 \pm 7 \mathrm{ng} / \mathrm{mL}$. Efek obat terhadap tubuh pada dasarnya merupakan akibat interaksi obat dengan reseptornya, maka secara teoritis interaksi efek obat, baik efek terapi maupun efek toksik, tergantung dari dosis yang diberikan. Interaksi tersebut menghasilkan perubahan biokimiawi dan fisiologis. Hormon GnRH sintetik dengan dosis 10-100 $\mu \mathrm{g}$ secara intravena menyebabkan peningkatan kadar gonadotropin plasma dengan cepat. Hormon bekerja secara normal pada kadar tertentu sesuai dosis yang diberikan, penurunan atau peningkatandosis dapat menurunkan potensi biologis hormon terhadap targetnya (Dewantoro et al., 2017).

Sari et al. (2018), menegaskan bahwa peningkatan kadar testosteron setelah perlakuan GnRH diakibatkan oleh hasil rangsangan terhadap hipofisis anterior. Mekanisme peningkatan dijelaskan oleh Weinbauer et al. (2000), bahwa GnRH dalam plasma berperan dalam merangsang pelepasan gonadotropin hormon (GtH). Kusuma (2012), menambahkan bahwa pelepasan hormon gonadotropin hormon (GtH-I dan GtH-II) untuk merangsang neuron hipofisis anterior yang disekresikan oleh hipotalamus. Selanjutnya GtH-I dan GtH-II dilepaskan sehingga meningkatkan kadar serum. Senyawa GtH berfungsi dalam proses spermatogenesis untuk mensekresikan hormon steroid yaitu testosteron dan 17ß-estradiol. Senyawa GtH-I berperan dalam perkembangan dan poliferasi sel sertoli dalam mensekresikan ABP dan GtH-II berperan dalam mensekresikan testosteron. 
Proses spermatogenesis dapat dipengaruhi oleh kadar testosteron dan FSH (Gartner dan Hiatt, 2001). Testosteron yang disekresikan oleh sel Leydig memiliki efek timbal balik dalam menambah kandungan LH (Faldikova et al., 2001). Hormon LH berikatan dengan reseptor LH oleh sel Leydig sehingga menyebabkan aktivasi adenilat siklase dan pembentukan Camp. Aktivasi protein kinase sel Leydig dan aktivasi kolesterol esterase akan menjadi testosteron yang dikonversi oleh kolesterol, ketika kadar testosteron di dalam darah tidak cukup untuk mempertahankan spermatogenesis. Dalam kondisi seperti itu maka FSH akan menginduksi sel Sertoli untuk melepaskan ABP sehingga kadar testosteron meningkat. Pelepasan LH dihambat karena tingginya kadar testosteron dan pelepasan FSH dihambat oleh inhibin (Gartner dan Hiatt, 2001).

Aktivasi sel-sel penghasil LH pada hipofisis ternak mengalami peningkatan melalui pemberian hormon GnRH yang diikuti dengan peningkatan pelepasan LH ke dalam darah kemudian didistribusikan pada sel-sel Leydig sebagai sel-sel tujuan LH (Pratomo, 2012). Testosteron memiliki peran yang sangat penting dalam spermatogenesis. Menurut Yusuf (2012), konsentrasi testosteron yang tinggi dalam cairan tubulus seminiferus penting untuk proses spermatogenesis. Syamyono et al. (2014), menambahkan tingginya kadar testosteron dapat meningkatkan produksi spermatozoa dan sekresi cairan plasma semen yang menyebabkan volume semen ikut meningkat.

\section{SIMPULAN}

Disimpulkan bahwa pemberian GnRH tidak berpengaruh terhadap peningkatan kualitas semen namun dapat meningkatkan level testosteron pada domba waringin.

\section{SARAN}

Diperlukan penelitian lanjutan dengan menggunakan metode koleksi semen dengan vagina biatansehingga diperoleh semen dengan kualitas lebih baik.

\section{UCAPAN TERIMA KASIH}

Tim penulis mengucapkan terima kasih kepada Ketua UPT. Hewan Coba Fakultas
Kedokteran Hewan Universitas Syiah Kuala atas fasilitas penelitian yang diberikan.

\section{DAFTAR PUSTAKA}

Afiati F, Yulnawati, Riyadi M, Arifiantini RI. 2015. Abnormalitas spermatozoa domba dengan frekuensi penampungan berbeda. Prosiding Seminar Nasional Masyarakat Biodiversitas Indonesia 1(4): 930-934.

Ahmad M, Asmat MT, Najib-Ur-Rehman. 2005. Relationship of testicular size and libido to age and season in Sahiwal bulls. Pakistan Vet J 25(2): 67-70.

Alam S. 2018. Potensi Pengembangan Ternak Domba Waringin. Majalah Infovet. Hlm. 23-26.

Azawi OI, Al-Khashab ANTM, Al-Khadoo NNA. 2012. Effect of gonadotropin releasing hormone treatment on semen characteristics and enzymatic activities of Awassi rams in breeding and non breeding seasons. Iranian J Appl Anim Sci 2(1): 13-19.

Bain J. 2010. Testosterone and the aging male: to treat or not to treat. J Maturitas 66(1): 16-22.

Barth AD, Oko RJ. 1989. Abnormal Morphology of Bovine Spermatozoa. Iowa. Iowa States University Press. Hlm. 34-37.

Dewantoro E, Rio N, Yudhiswara, Farida. 2017. Pengaruh penyuntikan hormon ovarium terhadap kinerja pemijahan ikan tengadak (Barbonymus schwanenfeldii). J Ruaya 5(2): 1-9.

Dewi RR, Hidayat R. 2018. Penampilan produksi domba Waringin jantan lepas sapih dengan pemanfaatan silase pucuk tebu dan ampas tahu. l Peternakan Unggul 1(1): 10-14.

Faldikova L, Diblikova I, Canderle J, Zraly Z, Veznik Z, Sulcova A. 2001. Effect of nutrition, social factors and chronic stress on the mouse Leydig cell testosterone production. Vet Med Czech 46(1): 160-168.

Garner DL, Hafez ESE. 2000. Spermatozoa and Seminal Plasma. Hafez, B., and Hafez, E.S.E. (ed.). In Reproduction in Farm Animals. $7^{\text {th }}$ ed. Philadelphia. Lippincott Williams and Wilkins. Hlm. 67-73. 
Gartner LP, Hiatt JL. 2001. Color Textbook of histology. New Jersey. Pearson Prentice Hall. Hlm. 54-57.

Gholib, Wahyuni S, Kadar OH, Adam M, Lubis TM, Azhar, Akmal M, Siregar, TN, Armansyah T, Nugraha TP. 2016. Pengukuran testosteron kambing kacang dengan teknik enzyme-linked immunosorbent assay (ELISA): pentingnya validasi kit. $J$ Kedokteran Hewan 1(1): 32-36.

Glover TD, D’Occhio MJ, Millar RP. 1990. Male Life Cycle and Seasonality. In: Marshall's Physiology of Reproduction. Vol II. Reproduction in the Male. Lamming GE (Ed.), 4th Ed. London. Churchill Livingstone.

Hafez ESE, Hafez B. 2000. Reproduction in Farm Animal ( $7^{\text {th }}$ ed). Philadelphia. Lippincott Williams and Wilkins. Hlm. 8794.

Hamdan. 1999. Pengaruh Pemberian GnRH (Gonadotropin Releasing Hormone) terhadap Kualitas Semen dan Kadar Testosterone Serum Kambing Peranakan Ettawah. Tesis. Yogyakarta. Universitas Gadjah Mada.

Hasbi H, Gustina. 2018. Regulasi androgen dalam spermatogenesis untuk meningkatkan fertilitas ternak jantan. Wartazoa 28(1): 13-22.

Herbert CA, Trigg TE, Renfree MB, Shaw GD, Eckery C, Cooper DW. 2004. Effect of a gonadotropin releasing hormone agonist implant on reproduction in male Marsupial, Macropus eugenii. Biol Reprod 70: 18361842.

Herdis. 2017. Karakteristik semen domba garut tipe laga pada tiga waktu penampungan semen. Zoo Indonesia 26(1): 8-19.

Ismaya. 2014. Bioteknologi Inseminasi Buatan pada Sapi dan Kerbau. Yogyakarta. Gadjah Mada University Press. Hlm. 6-9.

Johnson LA, Weitze KFP, Fiser G, Maxwell WMC. 2000. Storage of boar semen. J Anim Sci 62: 143-172.

Knol BW, Dielemen SJ, Bevers MM, Brom WEVD. 1993. GnRH in the male dog: doseresponce relationshipp with $\mathrm{LH}$ and testosteron. J Reprod Fertil 98(1): 159-161.
Kuiri-Hänninen T, Seuri R, Tyrväinen E, Turpeinen U, Hämäläinen E, Stenman UH, Dunkel L, Sankilampi U. 2011. Increased activity of the hypothalamicpituitarytesticular axis in infancy results in increased androgen action in premature boys. J Clin Endocrinol Metab 96: 98-105.

Kusuma PSW, Marhendra APM, Aulanni’am, Marsoedi. 2012. Mechanism of gonadotropin hormone release in catfish (Clarias sp) upon laserpuncture exposure to reproduction acupoint. Int J Basic Appl Sci 12(6): 177182.

Monaco D, Fatnassi M, Padalino B, Aubé L, Khorchani T, Hammadi M, Lacalandra GM. 2015. Effects of a GnRH administration on testosterone proûle, libido and semen parameters of dromedary camel bulls. Res Vet Sci 102: 212-216.

Mughniati S, Sari DK, Rendrawan D, Rahim L. 2018. Pengaruh ekstrak biji kapuk (Ceiba pentandra gaertn) sebagai obat kontrasepsi terhadap kualitas spermatozoa pada kucing lokal (Felis domestica). J Riset Vet Indonesia 2(1): 27-34.

Parakkasi A. 1981. Ilmu Gizi Ternak Pedaging. Bogor. Fakultas Peternakan IPB. Hlm. 3537.

Pratomo H, Yudi. 2016. Pemberian pasak bumi memengaruhi kadar testosteron dan spermatozoa kambing peranakan Etawa. $J$ Kedokteran Hewan 2(10): 148-153.

Pratomo H. 2010. Peningkatan Kadar Testosteron Serum Setelah Pemberian Seduhan Pasak Bumi. Tesis. Jakarta. Universitas Terbuka.

Puswell BJ, Wilcke JR. 1993. Response to gonadotropin-releasing hormone by the intact male dog: serum testosterone, luteizing hormone and follicle-stimulating hormone. J Reprod Fertil Suppl 47(1): 335340 .

Rochim D, Rahmat D, Heriyadi D, Bata M, Muchtar S, Ruslan Y, Martono Z. 2014. Domba Jumbo, Usaha Pembibitan dan Pembesaran. Trubus, Jakarta. Hlm. 6-2.

Rodriguez MH, Barth AD. 2007. In vitro evaluation of sperm quality related to in vivo function and fertility. Soc Reprod Fertil Suppl 64: 39-54. 
Sajjad M, Ali S, Akhter S, Ullah N. 2007. Effect of gonadotropin releasing hormone on semen characteristics in Nili- Ravi buffalo bulls. Pakistan Vet J 27(3): 153-154.

Sandra AN, Bebas W, Trilaksana IGNB. 2016. Motilitas dan viabilitas spermatozoa burung puyuh (Coturunix coturnix japonica) dalam pengencer fosfat kuning telur pada suhu $4^{\circ} \mathrm{c}$. Indonesia Medicus Veterinus 5(4): 296-303.

Sari RM, Rauza SR, Anas E. 2018. Pengaruh pemberian isolat katekin gambir (Uncaria gambir Roxb) terhadap kadar hormon testosteron dan jumlah spermatozoa tikus rattus norvegicus jantan hiperglikemia. $J$ Kesehatan Andalas 7(3): 6-9.

Schanbacher BD. 1978. Fertility of rams chronically treated with gonadotropin releasing hormone during nonbreeding season. Biol Reprod 19(1): 661-665.

Selvage DJ, Rivier C. 2003. Importance of paraventrilar bucaleus of the hypothalamus as a competent neural pathway between the brain and the tastes that modulates testosteron secretion independently of the pituitary. Journal of Endocrinology 144(2): 594-598.

Soehadi K, Arsyad KM. 1983. Analisis Sperma. Surabaya. Airlangga University Press. Hlm. 22-29.

Sujoko H, Setiadi MA, Boediono, A. 2009. Seleksi spermatozoa domba garut dengan metode sentrifugasi gradien densitas percoll. $J$ Veteriner 10(3): 125-132.

Sukaryana Y, Atmomarsono U, Yunianto VD, Supriyatna E. 2011. Peningkatan nilai kecernaan protein kasar dan lemak kasar produk fermentasi campuran bungkil inti sawit dan dedak padi pada broiler. J Ilmu dan Teknologi Peternakan 1(1): 167-172.

Syamyono O, Samsudewa D, Setiatin ET. 2014. Korelasi lingkar skrotum dengan bobot badan, volume semen, kualitas semen dan kadar testosteron pada kambing Kejobong muda dan dewasa. Buletin Peternakan 38(3): 132-140.

Tambing SN, Toelihere MR, Yusuf TL, Purwantara B, Sutama IK. 2003. Kualitas semen beku kambing Saanen pada berbagai jenis pengencer. Hayati 10(4): 146-150.

Tamoes JA, Nalley WM, Hine TM. 2014. Fertilitas spermatozoa babi landrace dalam pengencer modifikasi zorlesco dengan susu kacang kedelai. Sains Peternakan 12(1): 2030.

Toelihere MR. 1993. Inseminasi Buatan pada Ternak. Cetakan keenam. Bandung. Angkasa. Hlm. 57-62.

Wahid AS, Yunus JM. 1995. Level of testosterone in blood plasma of selected rams. AsianAustralasian J Anim Sci 8(6): 583-585.

Weinbauer GF, Gromoll J, Simoni M, Nieschlag E. 2000. Andrology: Male Reproductive Health and Dysfunction. 2nd Ed. New York. Springer. Hlm. 45-49.

WHO. 1999. Laboratory Manual for the Examination of Human Semen and Spermcervical Mucus Interaction. 4th ed. England. Cambridge University Press, Hlm. 102-115.

Yusuf M. 2012. Ilmu Reproduksi Ternak. Makassar. Jurusan Produksi Ternak Fakultas Peternakan Universitas Hasanuddin, Hlm. 27-34. 